\title{
Determining the extent of groundwater interference on the performance of infiltration
} trenches

Locatelli, Luca; Mark, Ole; Mikkelsen, Peter Steen; Arnbjerg-Nielsen, Karsten; Wong, Tony; Binning, Philip John

Published in:

Journal of Hydrology

Link to article, DOI:

10.1016/j.jhydrol.2015.08.047

Publication date:

2015

Document Version

Peer reviewed version

Link back to DTU Orbit

Citation (APA):

Locatelli, L., Mark, O., Mikkelsen, P. S., Arnbjerg-Nielsen, K., Wong, T., \& Binning, P. J. (2015). Determining the extent of groundwater interference on the performance of infiltration trenches. Journal of Hydrology, 529, 13601372. https://doi.org/10.1016/j.jhydrol.2015.08.047

\section{General rights}

Copyright and moral rights for the publications made accessible in the public portal are retained by the authors and/or other copyright owners and it is a condition of accessing publications that users recognise and abide by the legal requirements associated with these rights.

- Users may download and print one copy of any publication from the public portal for the purpose of private study or research.

- You may not further distribute the material or use it for any profit-making activity or commercial gain

- You may freely distribute the URL identifying the publication in the public portal 


\section{Determining the extent of groundwater interference on the performance of}

2 infiltration trenches

3 Luca Locatelli $^{\mathrm{a}}$, Ole Mark ${ }^{\mathrm{b}}$, Peter Steen Mikkelsen ${ }^{\mathrm{a}}$, Karsten Arnbjerg-Nielsen ${ }^{\mathrm{a}}$, Tony Wong ${ }^{\mathrm{c}}$,

$4 \quad$ Philip John Binning ${ }^{\mathrm{a}}$

6 a) Technical University of Denmark, Dept. of Environmental Engineering, Miljoevej, Building 113, $7 \quad 2800$ Kgs Lyngby, Denmark

8 b) DHI, Agern Allé 5, 2970 Hørsholm, Denmark

9 c) Cooperative Research Centre for Water Sensitive Cities, Monash University, Wellington Road, 10 Clayton, VIC 3800, Australia

\section{ABSTRACT}

Infiltration trenches are widely used in stormwater management, but their capacity decreases when installed in areas with shallow groundwater where infiltration is limited by groundwater drainage. Here the hydrological performance of single infiltration trenches in areas with shallow water tables is quantified in terms of their capability to reduce peak flow, peak volume and annual stormwater runoff volume. To simulate the long term hydrological performance of infiltration trenches two different models are employed. The models continuously simulate infiltration rates from infiltration 
trenches using a 19 year rainfall time series from Copenhagen as input. The annual and single event stormwater runoff reduction from infiltration trenches was determined for 9 different scenarios that covered different soil conditions and infiltration trench dimensions. Monte Carlo simulations were used in order to quantify the inpact of parameter variability for each scenario. Statistical analysis of the continuous long term model simulations was used to quantify the hydrological performance of infiltration trenches. Results show that infiltration trenches are affected by groundwater when there is an unsaturated depth of less than 1.5-3 $\mathrm{m}$ in sandy loam, 6.5-8 $\mathrm{m}$ in silt loam and 11-12 $\mathrm{m}$ in silty clay loam. A correction factor that can be applied for infiltration trench design when there is a shallow groundwater table is presented. The analyses showed that below a certain value of unsaturated depth the dissipation capacity of the mound/groundwater becomes the dominant process determining the infiltration capacity from infiltration trenches. In these cases it is essential to consider the local groundwater conditions in the infiltration trench design process.

\section{INTRODUCTION}

Infiltration trenches are employed in many countries for stormwater infiltration as part of Water Sensitive Urban Design (WSUD) which aims at improving urban stormwater management (Fletcher et al., 2014; Revitt et al., 2003; Wong and Brown, 2009). Infiltration trenches do not require the use of land surface areas which is a big advantage particularly in dense urban areas. However the city scale application of stormwater infiltration is constrained by the existing infrastructure and built environment, economical aspects, groundwater levels, local drinking water assets, soil pollution and stormwater runoff water quality (Göbel et al., 2004; Mikkelsen et al., 1994; Revitt et al., 2003).

Several studies have investigated the impact of widespread stormwater infiltration on the drainage system at the urban scale and shown an overall reduction of peak flows, stormwater runoff volume (Xiao et al., 2007; Holman-Dodds et al., 2003; Elliot et al., 2009), and combined sewer overflows (Roldin et al., 2012a; Peters et al., 2007). These studies agreed that the performance of infiltration systems is highly dependent on the local conditions, and particularly the physical properties of the 
soil. However they did not explicitly account for the interaction of the infiltration system with groundwater.

Models are often used to evaluate infiltration trench performance and Elliott et al. (2007) presented a review of commercial software available for simulating the impact of WSUDs on the urban drainage system. Manglik et al. (2004) showed a method to quantify the groundwater response from multiple infiltration basins; Antia (2008) and Endreny and Collins (2009) showed case studies at the urban residential area scale; Maimone et al. (2011), Ku et al. (1992), Jeppesen (2010) and Göbel et al. (2004) presented case studies at the urban scale. These studies reached the conclusion that widespread stormwater infiltration increases groundwater levels and can create surface runoff, particularly for areas with poorly conductive soils and a shallow groundwater table; some of the studies recommended groundwater control strategies when planning for large scale stormwater infiltration.

A large number of studies have presented models to either design or predict infiltration rates from single infiltration trenches. Guo (1998) presented a steady-state surface-subsurface model to design trench infiltration basins taking into account the distance to the groundwater table; this model does consider the formation of mounds below the infiltration system, transient processes that affect the performances of the system and it neglects lateral infiltration from the basins. Dussaillant et al. (2004) presented a three layer model with subsurface flow described by Richards' equation for designing rain gardens; however this model also does not account for the formation of mounds below the infiltration unit. Browne et al. (2008) presented a one-dimensional model for infiltration rates from infiltration units that accounts for changing sorrounding soil moisture conditions and the continuous interaction between storage and surrounding soil; this model does not consider variation in the depth of the saturated zone and horizontal infiltration from the sides of the infiltration unit. Browne et al. (2012) presented a two-dimensional model to calculate infiltration rates from stormwater infiltration systems but did not consider the effects of local mounds. Thompson et al. 
(2010) used the software HYDRUS-2D to predict water-table mounding and the main factors affecting the watertable beneath infiltration basins and showed that mound heights increased as the thickness of both the unsaturated and saturated zones decreased and as the initial soil moisture, basin size and ponding depth increased. Carleton (2010) simulated the effect of stormwater infiltration from large basins on local groundwater mounding showing that analytical solutions based on the Hantush equation (Hantush, 1967) underestimate the maximum height of groundwater mounding by 15\% when compared to finite-difference simulations. Roldin et al. (2013) presented a model to simulate the infiltration rates from single infiltration trenches in the presence of groundwater table showing that infiltration rates significantly reduce as the groundwater mound gets closer to the bottom of the infiltration trench.

Others have examined the performance of infiltration systems in field experiments. Bergman et al. (2011) and Warnaars et al. (1999) collected data of inflow rates and water levels in experimental infiltration systems to estimate hydraulic conductivity and the development of clogging. Machusick et al. (2011) presented an equation describing the relationship between groundwater mounding, precipitation and groundwater temperature for a experimental field of approximately 0.5 ha.

None of the papers reviewed above employed long term model simulation to quantify how the hydrological performance of infiltration trenches is affected by the distance to the groundwater table. Such a quantification is important because infiltration trenches are intended to be a key element in water management of urban areas and so clear design rules should be available. Two different models were used, one that considers the interaction with groundwater and one that does not. The annual and single event stormwater runoff reductions from infiltration trenches were quantified for 9 different scenarios that covered common soil types and infiltration trench designs encountered in Denmark. This study also introduces a correction factor to be used in the design process of infiltration trenches in the presence of a shallow groundwater table. This factor can be used to correct the infiltration trench design volume to account for the effect of the distance 
between the infiltration trench bottom and the groundwater. This factor is calculated for the 9 different scenarios as a function of the distance between the infiltration trench bottom and the groundwater.

The results are intended to support practitioners and decision makers by quantifying key hydrological performances and improving the actual design of infiltration trenches in the presence of a shallow groundwater table.

\section{MATERIALS AND METHODS}

Figure 1 shows the system that is modeled in this paper. The infiltration trench has a width $B$, a height $H$ and a length $L$ (perpendicular to the drawing) and receives stormwater runoff from the connected impervious area. When the water level $h$ in the infiltration trench is above 0 , infiltration occurs and when $h$ exceeds the infiltration trench height $H$ overflow to the sewer system occurs. Infiltrated stormwater percolates and recharges the unconfined groundwater aquifer which has a saturated thickness $h_{s}$. The unsaturated distance between the bottom of the infiltration trench and the initial undisturbed groundwater table is here referred to as $h_{u s}$. The height of the groundwater mound below the centerline of the infiltration trench is called $d$. The groundwater is assumed to have fixed head at a distance $1 / 2 L_{\text {drain }}$ from the center of the infiltration trench.

\subsection{The infiltration trench models}

Two different models were used in this study. The first model was developed by Warnars et al. (1999) and Roldin et al. (2012b) and includes no groundwater interaction and so is referred to as the 'Simple Model' (SM). The second model includes groundwater interaction (Roldin et al., 2013) and is here referred to as 'Model with Mounding' $(M M)$. Table 1 summarizes the parameters of the 2 models.

The mass balance of the infiltration trench is the same in both models and is given by: 
122 where $B$ is the width of the infiltration trench, $L$ is the length of the infiltration trench, $\varphi$ is the 123 porosity of the infiltration trench filling material, $h$ is the water level in the infiltration trench, $Q_{\text {in }}$ 124 and $Q_{\text {out }}$ are the inflow and outflow rates from the infiltration trench, and $t$ is time. The outflow 125 from the infiltration trench $Q_{o u t}$ is:

127 where $Q_{\text {infiltration }}$ is the infiltration rate and $Q_{\text {sewer }}$ is the overflow rate to the sewer pipe.

128 The inflow to the infiltration trench $Q_{\text {in }}$ is calculated as:

$Q_{\text {in }}=A S R \cdot i \cdot(B \cdot H \cdot L \cdot \varphi)=$ Area $\cdot i \cdot \varphi$

where ASR (Area/Storage Ratio) is the design criteria defined as the connected impervious area per unit volume of infiltration trench $\left[\mathrm{m}^{2} / \mathrm{m}^{3}\right] ; i$ is the rain intensity, $H$ the infiltration trench height and Area is the connected impervious area. Equation (3) is written as above because typical design procedures specify the Area/Storage Ratio for a given infiltration trench geometry $B H L$, return period and connected impervious area. Here an infiltration trench design was selected for a number of scenarios according to Danish design standards (Petersen et al., 1994, 1995). The designs for these scenarios aim at storing the stormwater volume accumulated during design events of a specified return period determined using the Danish regional IDF curves (Madsen et al., 2009).

The infiltration trench in this paper was assumed to be infinitely long (no flow in the longitudinal direction of the infiltration trench). This assumption produces an underestimation of the hydrological performance since in reality the flow is 3-dimensional and some water will infiltrate through the ends of the trench. The underestimation is negligible for infiltration trenches where the length $L$ is large compared to the cross section $B H$. The porosity of the filling material was assumed to be $\varphi=1$, i.e. the simulations represent infiltration trenches with a modern filling material having a 
144 very high porosity. Such porous filling material is commonly used in Danish infiltration trenches

145 (Roldin et al., 2012a; Roldin et al., 2012b; Roldin et al., 2013) .

\section{The 'Simple model' (SM)}

147 The Simple Model is based on the infiltration trench mass balance (Eq. 1) and the infiltration rate

$Q_{\text {infiltrationsm }}$ from the infiltration trench is calculated according to Eq. 4.

$Q_{\text {infiltrationsM }}=K B L+2 K(h L+h B)$

150 Where $B$ is the width of the infiltration trench, $L$ is the length of the infiltration trench, $h$ is the water

151 level in the infiltration trench, and $K$ is the saturated hydraulic conductivity. This study assumes

152 isotropic, uniform and no-clogging conditions. This was done for simplicity and is justified by the

153 fact that infiltration tests often do not distinguish between vertical and horizontal hydraulic

154 conductivity, and guidelines like CIRIA (2007) suggest regular maintenance to ensure proper

155 infiltration rates. However, other studies assumed no infiltration from the bottom in order to safely

156 account for clogging. For example, Peters et al. (2007) measured infiltration rates through the sides

157 to be 3-4 times bigger than bottom infiltration rates. Bergman et al. (2011) showed that clogging

158 reduced initial infiltration rates of 2 infiltration trenches by a factor of 3-4 after 20 years of

159 operation. Roldin et al. (2012a) used a horizontal hydraulic conductivity 2 times higher compared to 160 the vertical. In this paper, horizontal and vertical hydraulic conductivity were gathered into a single 161 parameter $K$ which can be interpreted as an effective saturated hydraulic conductivity.

\section{The 'Model with Mounding' (MM)}

163 The Model with Mounding is based on the infiltration trench mass balance (Eq. 1) with the

164 infiltration rate being modified according to Eq. (5). 
where $\theta_{s}$ is the saturated moisture content, $\theta\left(h_{u s}-d\right)$ is the moisture content at the bottom of the infiltration trench and $\theta\left(h_{\text {us }}\right)$ is the moisture content at the bottom of the infiltration trench, which is located at the distance $h_{u s}$ above the groundwater table. Eq. (5) shows that the infiltration rate approaches that of the Simple Model (which is assumed to be equal to the hydraulic conductivity, i.e. a unit-gradient Darcy flux) when the mounding height $d$ is small whereas it decreases as a function of the soil moisture retention curve and becomes 0 when the top of the mound $d$ reaches the infiltration trench bottom (this means that the infiltration rate from the trench equals the groundwater mound dissipation rate when the mound approaches the bottom of the trench). In reality the mounding can grow up to the water level in the infiltration trench, this means that the infiltration in the Model with Mounding is underestimated especially when $h_{\text {us }}$ approaches 0 . In practice an infiltration trench with the bottom placed right at the ground water table height $\left(h_{u s}=0\right.$ m) would infiltrate some water whereas it does not in the model $M M$.

The water content $\theta$ is calculated according to the Van Genuchten soil moisture constitutive relation (Van Genuchten, 1980):

$\theta(\Psi)=\theta_{r}+\frac{\theta_{S}-\theta_{r}}{\left(1+(\alpha|\Psi|)^{n}\right)^{m}}$

where $\theta_{r}$ is the residual moisture content, $\theta_{s}$ is the saturated moisture content, $\psi$ the pressure head and $\alpha, n$ and $m$ are the specific soil parameters. Eq. (6) is applied with Eq. (5) using $\psi=h_{u s}-d$ (see Figure 1).

The depth of the mound in the model $M M$ of Roldin et al. (2013) is calculated at each model time step using the analytical solution of the Hantush equation based on a finite Fourier sine transform series (Rao and Sharma, 1983). The depth of the mound is then used to calculate the infiltration rates in Eq. (5) in the following time step.The analytical solution is a 2D solution that computes the height of the groundwater throughout the $L_{\text {drain }}$ domain and assumes a constant water level at the boundaries of the domain. This boundary can be interpreted as an open water body, a stream or a 
190

191

192

193

194

195

196

197

drainage pipe. The extent of the drainage area is defined by the parameter $L_{d r a i n}$ and the groundwater domain is assumed to be symmetrical with respect to the center of the infiltration trench.

\subsection{Model scenarios}

The two different infiltration trench models discussed in Section 2.1 were used to run continuous simulations (transient simulations) of 19 years based on input rainfall data collected at a rain gauge in Copenhagen between 1992 and 2010 (the rainfall time series has a 1 minute time step).

Continuous simulations show the time development of the groundwater mound, the water content in the infiltration trench and the infiltration rates as a function of the input rainfall pattern and the other model parameters. The model time step was set to be 10 minutes. The time step is a compromise between calculation time and accuracy of the simulated 10 minute peak flow reduction shown in Section 2.3. Computing all the simulations with a 1 minute time step would require approx 90 days (using 9 processors) compared to 4 days when using a time step of 10 minutes. A comparison between simulation results using 1 and 10 minute model time steps was made for 50 simulations (using the $S M$ ). The comparison showed that the 10 minute time step overestimates the resulting peak flow reductions by an average of 4\%. Campisano et al. (2015) presented a thourough analysis considering several modeling time steps for rainwater tanks and showed less than 5\% difference in peak flow reduction going from a 5 minute to a 15 minute time step.

The 'Model with Mounding' was run with a 3 year warm up period (3 years of warm up followed by 19 years of simulation) because the mound takes approximately 2 years to develop in the slowest scenarios (The initial conditions of the warm up period are an empty infiltration trench, $h=0$ and a flat groundwater table $d=0$ ). This suggests that the performance of infiltration trenches in areas affected by shallow groundwater decreases during the period immediately after the installation until the mound is fully established. The mound can develop in a few months in highly conductive soils, 
while it can take several years in less conductive soils with a long drainage distance $L_{d r a i n}$. The 'Simple model' was run with the same warm up period although this was not strictly necessary.

9 different scenarios were run, each with approximately 1300 Monte Carlo simulations (tests showed that more than 1000 simulations were needed to obtain good results). The idea behind these scenarios was to cover typical soil types and different infiltration trench designs. The trench sized were defined to be 'small', 'medium' or 'large'. The parameter space was sampled using Latin Hypercubic Sampling (Helton and Davis, 2003). The uncertainty (Zimerman, 2000) of the input parameters (due to measurement uncertainty, spatial variability and design choices) was assumed to have Normal, Log-normal and Uniform distribution depending on the parameters. The model scenarios (S1-S9) with a description of the input parameter uncertainty are summarized in Tables 2 and 3.

Table 2 shows the ASR and the 'Storage depth' (defined as storage volume per impervious area or the inverse of $A S R$ ) for the scenarios considered. $B$ and $H$ were varied according to common trench geometries encountered in residential areas in Denmark. $h_{u s}$ was varied according to preliminary results which determined the range of $h_{u s}$ affecting the infiltration trench performance. $h_{s}$ was assumed to vary between 1 and 10 meters in all the scenarios; this distance was chosen according to preliminary results which showed that the saturated depth mostly influenced the infiltration trench performance for $h_{s}<10 \mathrm{~m}$, however saturated thickness can be much larger (this means that results slightly underestimate actual infiltration trench performance). $L_{d r a i n}$ was assumed to vary between 40 and $800 \mathrm{~m}$. $1 / 2 L_{\text {drain }}$ physically represents the distance to a open water body, a stream, a drainage pipe, a foundation drain, or any other underground draining path that can be found in an urban area. This distance was selected after considering the work of Malaguerra et al. (2012) who showed that the median distance between thousands of drinking water wells in Denmark and streams is in the order of $450-500 \mathrm{~m}$. 
238 Three different soils were considered for the model scenarios (as shown in Table 2): loamy sand,

239 silt loam and silty clay loam. The corresponding soil parameters were derived from Carsel et al.

240 (1988) and are summarized in Table 3.

\subsection{Model outputs}

We analyze three different model outputs:

- Annual storm water runoff reduction

- Single event stormwater runoff peak reduction

- Single event stormwater runoff volume reduction

246 Here the stormwater runoff reduction is defined as:

reduction $=100\left(1-\frac{Q_{\text {sewer }}}{Q_{\text {in }}}\right) \quad[\%]$

where $Q_{\text {in }}$ is the storm water runoff inflow rate to the infiltration trench and $Q_{\text {sewer }}$ is the overflow rate to the sewer pipe. Results for reduction are shown per unit length of infiltration trench.

The annual stormwater runoff reduction, defined as the ratio between the annual infiltrated stormwater volume and the annual stormwater inflow volume into the infiltration trench, was calculated for each model scenario and for each year of the 19 year continuous simulation. The results show the annual stormwater runoff reduction from the Monte Carlo simulations for both the $S M$ and the $M M$. Therefore the results will include both the effect of the input parameter uncertainty and the inter-annual variability of annual stormwater runoff reduction.

Results are presented for two different cases, the case where groundwater does not affect the performance of infiltration trenches $(S M)$, and the case where it does $(M M)$. The definition of whether groundwater does or does not influence the infiltration trench performance was determined as follows. The annual stormwater runoff reduction was found as a function of the unsaturated depth (Model with Mounding) and then a threshold value above which the influence of unsaturated 
depth becomes insignificant was determined. This threshold value was calculated for each scenario and was defined as the point where the mean annual runoff from the Model with Mounding equals 95\% of the mean annual runoff from the Simple Model.

For a better understanding of the uncertainty in the results, the annual stormwater runoff reduction was also determined as a function of the most sensitive parameters (unsaturated depth $h_{u s}$, saturated depth $h_{s}$, length of the domain $L_{d r a i n}$ and infiltration trench cross section $B$ ).

Single rainfall events are defined as being separated by dry weather of more than one hour duration. The single event peak flow and volume reductions were also calculated with both models. Single event peak reduction is defined as the ratio between the maximum single event 10 minutes overflow intensity from the infiltration trench (relative to the runoff area) and the maximum single event 10 minutes rainfall intensity. Single event volume reduction is defined as the ratio between the single event overflow volume from the infiltration trench (relative to the runoff area) and the single event rainfall volume. Results are shown as a function of the rainfall return period and for each of the 9 scenarios.

The single event peak and volume stormwater runoff reduction was obtained as follow:

- Compute the maximum 10 minute intensity and the total volume $Q_{\text {in }}$ and overflow to the sewer for each event in the simulated time series.

- Sort the 10 minutes intensities and the total volume of $Q_{\text {in }}$ and overflow per event in descending order.

- Calculate the single event peak reduction and the single event volume reduction as defined above.

- Assign to each reduction a return period $T$ [years] calculated using the Weibull (1939) plotting position: 


$$
T=\frac{y+1}{r}
$$

where $y$ is the duration of the time series in years and $r$ is the rank of the single rain event.

285 The results allow the calculation of the reduction for single rainfall events with a return period in the range of 5-10 and 0.5-1 years. 0.5-1 year return period events typically cause CSOs and sewer surcharge, and 5-10 years is the common design return period adopted in Denmark for urban drainage infrastructure.

\section{Sensitivity analysis}

290 A sensitivity analysis was carried out for the 9 scenarios and the two models using linear regression 291 of Monte Carlo simulations (Sin et al., 2010) for the ‘annual stormwater runoff reduction’. The 292 results show the standardized regression coefficients (Sin et al., 2010) for the parameters of the two 293 models.

\subsection{Correction factor}

An empirical correction factor to be applied to the designed infiltration trench volume is proposed. Common tools available to design infiltration trenches use simple models that assume infiltration rates similar to Equation 4. The infiltration rates from such models are a function of the infiltration trench geometry and soil hydraulic conductivity. Nevertheless the formation of mounds reduces infiltration rates. We therefore present a correction factor $\beta$ to calculate a corrected infiltration trench volume per unit length of infiltration trench $\mathrm{BH}_{1}$ for cases influenced by mounding.

$$
B H_{1}=\beta \cdot B H \cdot \varphi
$$

The correction factor will be presented as a function of unsaturated depth $h_{u s}$ for the 9 scenarios introduced in Section 2.3, and $B H$ is the infiltration trench cross section volume per unit length. $\beta$ is calculated using the Model with Mounding and with the following procedure for each of the 9 scenarios: 
- Select the parameters of an average performing infiltration trench (according to the results that show average reduction and corresponding uncertainty bounds) of 1x1m cross section. The average performing infiltration trench is an infiltration trench having mean annual runoff reduction from the $M M$ model similar to the mean annual runoff reduction from the SM model.

- $\quad$ Select a discrete number of unsaturated depths $h_{u s}$ at which $\beta$ will be computed.

- $\quad$ The parameter $\beta$ was obtained by parameter optimization using the Model with Mounding. The objective function was the mean annual runoff reduction obtained from the Simple model and shown later in Figure 2. Optimization was done using the DREAM optimization software (Vrugt et al., 2009) which employs the Shuffled Complex Evolution Algorithm.

\section{RESULTS}

\subsection{Annual stormwater runoff reductions}

Figure 2 shows the annual runoff reduction from the Simple Model. These results are considered valid for infiltration trenches without the influence of groundwater, i.e. infiltration trenches that are above a certain distance $h_{u s}$ from the groundwater; later in this section we discuss the effect of the distance $h_{u s}$ on infiltration trench performance. The uncertainty bounds of annual runoff reduction include the effect of inter-annual variation and uncertainty of model input parameters and particularly $K$. The effect of inter-annual variation of annual runoff reduction was estimated to influence the mean annual runoff reduction by 10-15\%. Locatelli et al. (2015) showed that a soakaway of $1.9 \mathrm{~m}^{3} / \mathrm{m}^{2}$ in a soil with $K=8.210^{-7} \mathrm{~m} / \mathrm{s}$ has an annual runoff reduction of $68-87 \%$ depending on the year. The results show that:

- Infiltration trenches in loamy sand reduce annual runoff by an average of 92-100\% with limited uncertainty and thus high confidence. This suggests that infiltration trenches in 
loamy sand, i.e. in soils with an average hydraulic conductivity in the order of $4 \cdot 10^{-5} \mathrm{~m} / \mathrm{s}$, that are designed to have at least 4-5 mm of storage depth (S1) and are not influenced by groundwater, have an annual runoff reduction in the order of $92 \%$.

- Infiltration trenches in silt loam reduce annual runoff by an average of 61-73\% with a great uncertainty. This suggests that infiltration trenches in silt loam, i.e. in soils with an average

- Infiltration trenches in silty clay loam reduce annual runoff by an average of $38-57 \%$ with a hydraulic conductivity on the order of $1 \cdot 10^{-6} \mathrm{~m} / \mathrm{s}$, can significantly reduce annual runoff; however their performance is highly uncertain. large uncertainty. This suggests that infiltration trenches in silty clay loam, i.e. in soils with an average hydraulic conductivity in the order of $2 \cdot 10^{-7} \mathrm{~m} / \mathrm{s}$, can contribute up to an average of 57\% annual runoff reduction; however their performance is highly uncertain.

Overall results show a relatively small (up to a 20\%) increase in annual runoff reduction going from 'small' infiltration trenches to 'large' ones (from S1 to S3, from S4 to S6 or from S7 to S9). Increasing infiltration trench size from 'small' to 'large' requires a significant increase in storage depth (see Table 2), e.g. the storage depth in the silty clay loam from scenarios S4 to S6 triples. This suggests that infiltration trenches designed to handle low return period events are likely to be more efficient (efficiency = annual infiltrated stormwater / storage depth) for annual runoff reduction than infiltration trenches designed to handle higher return period events. A similar conclusion was also given by Locatelli et al. (2015). Freni et al. (2009) showed that an infiltration unit of $0.4 \mathrm{~m}^{3} / 100 \mathrm{~m}^{2}$ (storage depth $=4 \mathrm{~mm}$ ) in different soils with hydraulic conductivity within $6.1 \cdot 10^{-6}$ and $1 \cdot 10^{-4} \mathrm{~m} / \mathrm{s}$ could reduce the 6-year stormwater runoff by 28 $80 \%$ depending on the local soil conditions.

Figure 3 shows the annual stormwater runoff reductions from the Model with Mounding as a function of the unsaturated depth $h_{u s}$. The results confirm that the mean annual runoff reduction decreases to 0 as the unsaturated depth decreases to 0 . Figure 3 shows that the annual runoff 
reduction tends to a constant value (that is the same as the one obtained from the Simple Model) as the unsaturated depth increases above a certain threshold value. The threshold value of unsaturated depth was computed and shown in Table 4 for each scenario. The table shows that infiltration trenches implemented as shown in Figure 1 are not affected by groundwater if the unsaturated depth is above $\approx 1.5-3 \mathrm{~m}$ in loamy sand; above $\approx 6.5-8 \mathrm{~m}$ in silt loam and above $\approx$ 11-12 $\mathrm{m}$ in silty clay loam. There seems to be a decreasing trend in the threshold value within scenarios of the same soils for increasing infiltration trench storage depth (going from S1 to S3, or from S4 to S6). This is likely because the same infiltration trench cross section infiltrates less water as the Area/Storage ratio decreases (going from S1 to S3, or from S4 to S6) since less area is drained into a given trench volume; this results in a lower groundwater mound and thus a infiltration trench that can be constructed with a lower unsaturated depth. 
367 Figure 4 shows the annual stormwater runoff reduction for the $S M$ and $M M$ as a function of the 368 hydraulic conductivity $K$. Results are only shown for the $M M$ when the $h_{u s}$ influences the annual 369 runoff performance of infiltration trenches, as shown in Table 4.

The uncertainty bounds for the $S M$ (Figure $4 a, 4 b, 4 c$ ) are small and include the effect of $B, H, A S R$ variability and inter-annual variations. These results help understanding the uncertainty bounds shown in Figure 2, and clearly show that the uncertainty was mainly due to the variability of $K$. The uncertainty bounds for the $M M$ (Figure $4 d, 4 e, 4 f$ ) are wider and include the variabilty of $B, H$, $L_{d r a i n}, h_{s}, A S R$, inter-annual variations, and are mostly due $h_{u s}$ variability ( $K$ and $h_{u s}$ were found to be the 2 most influential parameters as shown later in the sensitivity analysis). These results help understanding the uncertainty bounds shown in Figure 3, and show that $K$ variability significantly contributed to such uncertainty.

Overall results show great variation of annual runoff reduction in the $K$ domain except for $S 1$ (Figure 4a). This means that infiltration trenches in loamy sand, i.e. in soils with an average hydraulic conductivity in the order of $4 \cdot 10^{-5} \mathrm{~m} / \mathrm{s}$ without the influence of groundwater, are most likely to give more than $78 \%$ annual runoff reductions if infiltration trenches are designed to have at least 4-5 mm of storage depth (S1 in Table 2).

Figure 4b and 4c (S4 to S5), i.e. infiltration trenches in silt loam and silty clay loam without the influence of groundwater, show annual runoff reduction in the range of 50-100\% if the hydraulic conductivity is above $K_{\text {mean }}$, however annual runoff reduction is significantly decreased for $K<$ $K_{\text {mean }}$

Figure 4b, 4c, 4d and 4f, i.e. infiltration trenches in silt loam and silty clay loam, show that the annual runoff reduction is highly reduced for hydraulic conductivity $<1 \cdot 10^{-7} \mathrm{~m} / \mathrm{s}$. 
These results suggest that it is relevant to check the spatial variability or site-to-site variability of $K$.

Local infiltration tests are recommended as suggested in many guidelines. Moreover infiltration trenches in soils with $K$ on the order of $1 \cdot 10^{-7} \mathrm{~m} / \mathrm{s}$ show average annual runoff reductions of $16-70 \%$ and require large storage depth 36-83 mm, much less efficient than in sandy loam. Bockhorn et al. (2014) showed that point measured infiltration rates are often an order of magnitude lower when compared to infiltration rates measured in full trench infiltration tests in clay till and sandy clay till. This suggests that the infiltration process from infiltration trenches is likely to be a function of higher values than the locally measured $K_{\text {mean }}$. This implies that modeled infiltration rates of an infiltration unit using the mean hydraulic conductivity are likely to underestimate trench performance.

Similar results were found in the literature. Bergman et al. (2011) modelled the performance of 2 infiltration trenches of $8 \mathrm{~m}^{3}$ connected to an impervious area of $600 \mathrm{~m}^{3}$ (this corresponds to $75 \mathrm{~m}^{2}$ of impervious area for every $1 \mathrm{~m}^{3}$ of storage; or a storage depth of $13 \mathrm{~mm}$ ). For $K$ in the range of $3 \cdot 10^{-7}-2 \cdot 10^{-6} \mathrm{~m} / \mathrm{s}$ they reported an annual runoff reduction of $94 \%$ and for $K$ in the range of $3 \cdot 10^{-7}$ $2 \cdot 10^{-6} \mathrm{~m} / \mathrm{s}$ they reported $40 \%$. Freni et al. (2009) modeled an infiltration trench of $0.4 \mathrm{~m}^{3} / 100 \mathrm{~m}^{2}$ (storage depth $=4 \mathrm{~mm}$ ) and reported annual stormwater runoff reductions of $28-30 \%$ in sandyloam; 34-39\% in loamy-sand; 38-66\% in sand and 45-80\% in gravel.

\section{The effect of $B, h_{s}, L_{d r a i n}$ variability on annual runoff reduction.}

Figure 5 shows the mean annual stormwater runoff reduction as a function of the infiltration trench width $B$ (Figure 5a for $S M$ and 5b for $M M$ ), the saturated depth $h_{s}$ (Figure 5c), and the draining length $L_{\text {drain }}$ (Figure 5 d). The uncertainty bounds were not shown in order to make the Figure easier to read, but uncertainties are of the same order of magnitude as those presented in Figure 3 and 4.

Figure 5a and 5b show that there is an almost linear relationship between annual runoff reduction and infiltration trench width $B$; the annual runoff reduction decreases as $B$ increases. This result can be explained by noting that for a given ASR (Area/ Storage Ratio) and H; a larger B means a larger 
connected impervious area, and a lower 'wetted area/storage volume ratio' of the infiltration trench. Moreover the results from $M M$ (Figure 5b) show larger slopes compared to the results from SM (Figure 5a) and this is likely because for a given ASR (Area/ Storage Ratio) and H, infiltration trench performance is affected by the infiltrated volume: the larger the $B$, the larger the infiltrated volume, the larger the mounding depth. The influence of the infiltration trench height $H$ is not shown as results are similar to the ones of $B$.

Figure 5c shows that the annual runoff reduction increases with saturated depth. This is because the higher the saturated depth, the higher the aquifer transmissivity and thus the lower the mounding height and the higher the infiltration rates. Similar observations were also made by Thompson et al. (2010) and Guo (1998). The loamy sand scenarios (S1, S2 and S3) show a higher variation of annual runoff reduction in the $h_{s}$ range of $0-3 m$ than silt loam scenarios (S4, S5 and S6), and even more than silty clay loam scenarios (S7, S8 and S9). This is likely because of the model setup, i.e. as $h_{s}$ approaches 0 , the groundwater dissipation also becomes 0 (for fixed groundwater gradients) and thus also the annual runoff reduction tends to 0 . Annual runoff reduction is significantly reduced for a saturated depth $h_{s}$ below 2-3m, particularly in sandy loam. This suggests that when implementing infiltration trenches it is relevant to have a saturated depth of at least couple of meters and that a higher saturated depth is to be preferred.

Figure $5 d$ shows that annual runoff reduction decreases as $L_{\text {drain }}$ increases. This is because the larger the drainage length the lower the groundwater gradients and thus the higher the mounding and the lower the annual runoff reduction. The $L_{d r a i n}$ is shown to be most influential in the sandy loam scenarios. These results underline the importance of taking into account groundwater drainage when infiltration trenches are implemented in shallow groundwater areas, particularly in sandy loamy soils.

\subsection{Single event peak and volume stormwater runoff reductions}


Figure 6 shows the single event peak and volume reduction for rain events of 0.5-1 year return period using the two models. For the given time series, 0.5-1 year return period events have a maximum 10 minute intensity in the range of 33-43 mm/h and a total rainfall volume per event in the range of 23-28 mm. Similar trends are observed for both the peak reduction results (Figure 6, a to c) and volume reduction (Figure 6, d to f).

Infiltration trenches in loamy sand that are designed for a 1 year return period or more (S2 and S3) show average peak and volume reduction above $94 \%$ if not affected by groundwater (SM), and 62$67 \%$ with large uncertainty if close to the groundwater (MM). Infiltration trenches in loamy sand can contribute significantly to peak and volume runoff reduction for rain events of 0.5-1 year return period, however if the unsaturated depth is $<1.5-3 \mathrm{~m}$ the performance can be significantly reduced (Figure 3). Infiltration trenches in loamy sand, i.e. in soils with an average hydraulic conductivity in the order of $4 \cdot 10^{-5} \mathrm{~m} / \mathrm{s}$ and without the influence of groundwater, can be designed to significantly reduce peak runoff and volume from rain events of 0.5-1 year return period; however their performance becomes uncertain for an unsaturated depth less than 1.5-3 m.

Infiltration trenches in silt loam show a highly uncertain peak and volume reduction with an average of 36-68 \% if not affected by groundwater (SM), and 18-37 \% if close to the groundwater (MM). Infiltration trenches in silt loam can contribute to peak runoff reduction for rain events of 0.5-1 year return period, however their performance is highly uncertain.

Infiltration trenches in silty clay loam show a highly uncertain peak volume reduction with an average of 16-43 \% if not affected by groundwater (SM), and 5-18 reduction if close to the groundwater (MM). Infiltration trenches in silt clay loam can contribute to peak and volume runoff reduction for rain events of 0.5 -1 year return period, however their performance is highly uncertain and quite low also considering the large storage depth required in such a soil.

Figure 7 shows the single event peak and volume reduction for rain events of 5-10 year return period using the two models. For the given time series it was calculated (not shown) that 5-10 year 
return period events have a maximum 10 minute intensity in the range of $64-67 \mathrm{~mm} / \mathrm{h}$ and a total rainfall volume per event in the range of $46-55 \mathrm{~mm}$. Similar trends are observed when comparing the peak reduction results (Figure 7, a to c) and volume reduction results (Figure 7, d to f).

Results from loamy sand scenarios and SM, i.e. for infiltration trenches that are not affected by groundwater, show that even an infiltration trench designed for a 0.1 y return period (S1) can contribute with an average 37\% reduction of single event runoff volume for 5-10 year return period events (Figure 7d). Moreover, if infiltration trenches not affected by groundwater are designed to handle 10 year return period events they can reduce on average $88-95 \%$ of the peak and volume from single events (Figure 1a and 1d). However, infiltration trenches that are affected by groundwater, i.e. for unsaturated depths $<1-5-3 \mathrm{~m}$, show single event peak and volume reductions significantly lower and with a higher uncertainty. Infiltration trenches not affected by groundwater and in loamy sand, i.e. in soils with an average hydraulic conductivity in the order of $4 \cdot 10^{-5} \mathrm{~m} / \mathrm{s}$, can significantly contribute to reduce peak and runoff volume from rain events of 5-10 year return period.

Results from the silt loam scenarios show that infiltration trenches not affected by groundwater can contribute with an average 8-54\% reduction (SM) of single event runoff peak and volume for 5-10 year return period events; and 4-23\% (MM) if affected by groundwater. Both the $S M$ and $M M$ show large uncertainties. Even though infiltration trenches in silt loam might contribute to volume runoff reduction of 5-10 year return period events, the performance is highly uncertain and to obtain significant reductions a large storage depth is required (at least 36-50mm of storage depth; S5, Table 2).

Infiltration trenches in silty clay loam show very low peak and volume reductions for 5-10 year return period events. Some reduction can be achieved by S9, however that scenario requires infiltration trenches of 67-83 mm storage depth (Table 3) which is large. This suggests that infiltration trenches in silty clay loam, i.e. in soils with an average hydraulic conductivity in the 
489

490

491

492

493

494

order of $1 \cdot 10^{-7} \mathrm{~m} / \mathrm{s}$, are not likely to be a good solution for single event peak and volume reduction of events of 5-10 year return period.

Campisano et al. (2011), reported a single event peak flow (for a selected design storm event) reduction of $<7 \%$ for an infiltration trench of $24 \mathrm{~mm}$ storage depth in soils with $K \leq 10^{-6} \mathrm{~m} / \mathrm{s}$, and a reduction of $37 \%$ in soils with $K=10^{-5} \mathrm{~m} / \mathrm{s}$.

Overall, results show that even if infiltration trenches are designed to handle peak and volume from 5-10 year return period events, their performance is highly uncertain with the exception of infiltration trenches in sandy loam without the influence of groundwater. It can also be seen that when infiltration trenches are designed to handle 5-10 year return period events they must have a large storage depth. These results suggest that infiltration tranches should not be designed with the aim of reducing single events peaks and volume from 5-10 year events. Moreover, infiltration trenches designed to handle more frequent $0.5-1$ year return period events can contribute to reduce peak and volume runoff but with high uncertainty. It should be noted that changing the design from a 0.1 year return period design to a 1 year return period requires a 2-3 times increase storage. This suggests that infiltration trenches should be used primarily the aim of reducing annual runoff. Having smaller storage depths also reduces the total infiltrated amount resulting in lower mounds. A similar conclusion was found by Locatelli et al. (2015), who showed that peak flows can be handled more efficiently by detention volumes rather than infiltration trenches.

\subsection{Sensitivity analysis}

The results of the sensitivity analysis for the two models are shown in Figure 8. For simplicity only the results from Scenario 5 are reported since there is not a significant difference in parameter sensitivity for the 9 scenarios. Sensitivity of the single event peak and volume reduction was also determined for Scenario 5 with similar results. 
The most influential parameter on the annual runoff reduction for the Simple Model is the hydraulic conductivity K. Area/Storage Ratio, $B$ and $H$ have a lower sensitivity scores and are shown to be negatively correlated, i.e. the higher the parameter the lower the annual runoff reduction. The sensitivity of the cross section $B \cdot H$ was similar to that of $H$ and $B$ individually, meaning that a smaller cross section would on average result in higher annual runoff reductions. This is because for a given ASR (Area/ Storage Ratio), a larger the cross section $B H$ results in a larger connected impervious area and a smaller wetted area/storage volume ratio of the infiltration trench. However this holds only for long infiltration trenches where the length $L$ is much larger than the cross section.

The most influential parameters for the Model with Mounding are the hydraulic conductivity $K$ and the unsaturated depth $h_{u s}$, whereas the Area/Storage Ratio, the saturated depth $h_{s}$, the length of the model domain $L_{\text {drain, }} B$ and $H$ have a lower sensitivity score. $h_{s}$ is shown to be negatively correlated to annual runoff reduction, i.e. the higher the saturated depth, the higher the aquifer transmissivity and thus the lower the mounding height and the higher the infiltration rates. $L_{d r a i n}$ is also negatively related to the annual runoff reduction. The extent of the drainage length $L_{\text {drain }}$ influences the equilibrium depth of the groundwater mound and thus the infiltration capacity from the infiltration trench, i.e. the higher the drainage length, the higher the height of the mound for a given gradient, resulting in lower infiltration rates. The soil parameters $n, \theta_{s}, \theta_{r}$ and $\alpha$ are shown to be the least influential parameters for the Model with Mounding. These parameters define the soil moisture distribution in the unsaturated zone. For example, the parameter $\alpha$ (the most influential of the parameters shown in Figure 8) controls the capillary height and its influence on the infiltration trecnh performance is expected to increase when the distance between the bottom of the infiltration trench and the groundwater table is in the same order of magnitude as the capillary height. $B$ and $H$ are negatively correlated for the same reasons as mentioned above. Similar observations were reported by Maimone et al. (2011) and Manglik et al. (2004). 


\subsection{Correction factor}

Figure 9 shows the correction factor as a function of the unsaturated depth. The results show that the correction factor increases rapidly and that there is a critical unsaturated depth below which the correction factor cannot influence the infiltration trench performance. This critical depth $h_{u s}$ is approximately 1-2m in loamy sand and 2-4m in silt loam and silty clay loam (see table 4). However the magnitude of this critical depth was only derived from a single simulation for each scenario. Moreover results are affected by model assumptions. For example, as already introduced in Section 2.1, the $M M$ model underestimates the performance of infiltration trenches for $h_{u s}$ approaching 0 meaning that the critical depth is underestimated.

These results suggest that below a certain value of unsaturated depth the dissipation capacity of the mound/groundwater becomes the dominant process determining the infiltration capacity from infiltration trenches, i.e. no matter how big the correction factor is, the infiltration trench performance is dictated by the mounding/groundwater dissipation capacity. When multiple infiltration trenches are implemented in the same area this effect becomes even more relevant. This suggests that when infiltration trenches are designed in an area of shallow groundwater, the design should be based on the local groundwater dissipation capacity and that proper groundwater drainage should be the primary consideration.

\subsection{Model limitations}

The $M M$ model assumes that the mound height cannot exceed the infiltration trench bottom. This is not realistic since in reality it can reach the water level in the infiltration trench. This implies an underestimation of infiltration rates that increases as the unsaturated depth $h_{u s}$ decreases to 0 .

The inflow rate $Q_{\text {in }}$ to the infiltration trench was assumed to be the same as the rainfall measured at the rain gauge, i.e. no initial loss was considered and there was no routing of the runoff from the 
impervious area to the infiltration trench. This implies a slight underestimation of the performance of infiltration trenches.

The infiltration trench was assumed to be infinitely long, i.e. no-flow in the longitudinal direction, this implies an underestimation of the infiltration rates as the infiltration trench length $L$ decreases to 0 . The results presented in the paper underestimate performance for infiltration trenches where the length $L$ is in the same order of magnitude as $B$ and $H$ (e.g. for near-square trench). Moreover, this model assumed an initially flat water table. However in reality there are small groundwater gradients that would produce asymmetric mounding and dissipation rates. However the impact is expected to be small, especially in areas of small groundwater gradients.

The models assumed isotropic and uniform conditions, i.e. the infiltration rate per unit wetted area of infiltration trench is assumed to be equal to the saturated hydraulic conductivity (i.e. unitgradient Darcy flow). However the horizontal hydraulic conductivity is generally higher than the vertical and heterogeneity and macro-pores are likely to increase the infiltration rates.

Clogging was not included into the model. This implies that the simulated performance of the infiltration trenches is overestimated (Bergman et al., 2011). Clogging is important to be considered where the periodic maintenance of infiltration systems is not planned.

This model assumes infiltration only from a single unit, whereas in reality multiple units would be installed. Widespread stormwater infiltration increases the groundwater levels and reduces the infiltration rates compared to our model.

In this paper a model with all of the above simplifications is employed, even while knowing that they cannot be completely justified. This was done because this model is the most realistic one that is still simple enough to run long-term simulations and complete the statistical analysis presented. More detailed models would be much more computationally expensive. Our results provide a first insight and demonstrate that more work is still needed such as simulations of the effects of multiple 
infiltration trenches placed close to each other and representing groundwater mounds above the trench bottom in the model.

\section{CONCLUSIONS}

This paper presents model results that quantify the effects of infiltration trench geometry, soil variability and the presence of a shallow groundwater table on the hydrological performance of single infiltration trench. Statistical analysis of continuous long-term simulations of 9 different scenarios was used to evaluate annual and single event runoff reduction from single infiltration trenches. Overall results showed that infiltration trenches can reduce annual runoff; that if the soil hydraulic conductivity is on the order of $1 \cdot 10^{-7} \mathrm{~m} / \mathrm{s}$ or lower, infiltration trenches might not be a good solution for handling urban runoff as they require large volumes (36-83 $\mathrm{mm}$ ) for average annual runoff reductions of $16-70 \%$; that it is important to include groundwater drainage in the design of infiltration trenches; that a saturated thickness of the unconfined aquifer of less than a few meters can significantly reduce the hydrological performance of infiltration trench; that the more the infiltrated runoff volume, the more the groundwater mound will reduce the infiltration trench performance. Results showed that the performance of infiltration trenches is affected by groundwater when there is an unsaturated depth of less than 1.5-3 $\mathrm{m}$ in sandy loam, 6.5-8 $\mathrm{m}$ in silt loam and 11-12 m in silty clay loam.

Moreover, this study suggests that infiltration trench should be designed with the aim of reducing annual runoff and are less effective for single event peak and volume runoff.

Finally the results from the correction factor showed that there is an unsaturated depth below which the infiltration trench performance is governed by the dissipation of the mound. This means that when designing infiltration trenches very close to the groundwater table the groundwater dissipation capacity should drive the design process. This suggests that infiltration trench design tools should consider groundwater, especially in areas with shallow groundwater and that infiltration trench 
608 design must be done cautiously when implementing infiltration systems with depth to groundwater 609 less than the threshold depths indicated for the different soil types.

\section{Acknowledgments}

611 The authors thank the Danish Council for Research that financed the present research through the 612 project BIV (Byer I Vandbalance/Cities in water balance). 


\section{References}

Antia, D. D. J., 2008. Prediction of overland flow and seepage zones associated with the interaction of multiple infiltration infiltration devices (cascading devices). Hydrological Processes 22(14): 2595-2614.

Bergman, M., Hedegaard, M.R., Petersen, M.F., Binning, P., Mark, O., Mikkelsen, P.S., 2011. Evaluation of two stormwater infiltration trenches in central Copenhagen after 15 years of operation. Water Sci. Technol. 63 (10), 2279-2286.

Bockhorn, B., Klint, K.E.S., Jensen, M.B., Møller, I., 2014. Using geological mapping tools to improve the work efficiency of SUDS. 13th IAHR/IWA International Conference on Urban Drainage. 7th-12th September, 2014. Malaysia.

Browne, D., Deletic, A., Mudd, G.M., Fletcher, T.D., 2008. A new saturated/unsaturated model for stormwater infiltration systems. Hydrological Processes 22(25): 4838-4849.

Browne, D., Deletic, A., Mudd, G. M., Fletcher, T.D., 2012. A two-dimensional model of hydraulic performance of stormwater infiltration systems. Hydrological Processes.

Campisano, A., Creaco, E., Modica, C., 2011. A simplified approach for the design of infiltration trenches. Water Science and Technology 64: 6. 1362-1367.

Campisano, A., Modica C., 2015. Appropriate resolution timescale to evaluate water saving and retention potential of rainwater harvesting for toilet flushing in single houses. Journal of Hydroinformatics 17: 3. 331-346.

Carleton, G.B., 2010. Simulation of groundwater mounding beneath hypothetical stormwater infiltration basins, U.S. Geological Survey. Scientific Investigations Report 2010-5102.

Carsel, R.F., Parrish, R.S., 1988. Developing joint probability distributions of soil water retention characteristics. Water Resources Research 24(5): 755-769.

CIRIA. 2007. The SUDS manual (C697). CIRIA, Classic House, 174-180 Old Street, London, EC1V 9BP, UK. ISBN 978-0-86017-697-8. 
Dussaillant, A., Wu, C., Potter, K., 2004. Richards Equation Model of a Rain Garden. Journal of Hydrologic Engineering 9(3): 219-225.

Elliott, A.H., Trowsdale S.A., 2007. A review of models for low impact urban stormwater drainage. Environmental Modelling \&amp; Software 22(3): 394-405.

Elliott, A.H., Trowsdale S.A., Wadhwa, S., 2009. Effect of Aggregation of On-Site Storm-Water Control Devices in an Urban Catchment Model. Journal of Hydrologic Engineering 14(9): 975-983.

Endreny, T., Collins, V., 2009. Implications of bioretention basin spatial arrangements on stormwater recharge and groundwater mounding. Ecological Engineering 35(5): 670-677.

Fletcher, T.D., William, S., Hunt, W.F., Ashley, R., Butler, D., Scott, A.,Trowsdale, S., Barraud, S., Semadeni-Davies, A., Bertrand-Krajewski, J.L., Mikkelsen, P.S., Rivard, G., Uhl, M., Dagenais, D., Viklander, M., 2014. SUDS, LID, BMPs, WSUD and more - The evolution and application of terminology surrounding urban drainage. URBAN WATER JOURNAL: $1-18$

Freni, G., Mannina, G., Viviani, G., 2009. Stormwater infiltration trenches: a conceptual modelling approach. Water Science \& Technology.

Göbel, P., Stubbe, H., Weinert, M., Zimmermann, J., Fach, S., Dierkes, C., Kories, H., Messer, J., Mertsch, V., Geiger, W.F., Coldewey, W.G., 2004. Near-natural stormwater management and its effects on the water budget and groundwater surface in urban areas taking account of the hydrogeological conditions. J. Hydrol. 299, 267-283.

Guo, C.Y., 1998. Surface-subsurface model for trench infiltration basins. Journal of Water Resources Planning and Management-Asce 124(5): 280-284.

Helton, J. C. and F. J. Davis 2003. Latin hypercube sampling and the propagation of uncertainty in analyses of complex systems. Reliability Engineering \& System Safety 81(1): 23-69.

Hantush, M.S., 1967. Growth and decay of groundwater-mounds in response to uniform percolation. Water Resour. Res. 3, 227-234. 
Holman-Dodds, J.K., Bradley, A.A., Potter, K.W., 2003. Evaluation of Hydrologic Benefits of Infiltration Based Urban Storm Water Management. J. of the American Water Resources Association (JAWRA) 39(1):205-215.

Jeppesen, J., 2010. Quantitative Hydrological Effects of Urbanization and Stormwater Infiltration in Copenhagen, Denmark. PhD Thesis. Department of Earth Sciences, Aarhus University, Denmark.

Ku, H.F.H., Hagelin, N.W., Buxton, H.T., 1992. Effects of Urban Storm-Runoff Control on Ground-Water Recharge in Nassau County, New York. Ground water 30(4): 507-514.

Locatelli, L., Gabriel, S., Mark, O., Mikkelsen, P.S., Arnbjerg-Nielsen, K., Taylor, H., Bockhorn, B., Larsen, H., Kjølby, M.J., Steensen Blicher, A., Binning, P.J., 2015. Modelling the impact of retention-detention units on sewer surcharge and peak and annual runoff reduction. Water science and technology. 98-903.

Machusick, M., Welker, A., Traver, R., 2011. Groundwater mounding at a stormwater infiltration BMP. J. Irrigat. Drainage 137, 154-160.

Madsen H., Arnbjerg-Nielsen K., Mikkelsen P.S., 2009. Update of regional intensity-durationfrequency curves in Denmark: Tendency towards increased storm intensities. Atmospheric Research, 92(3), 343-349.

Maimone, M., O’Rourke, D.E., Knighton, J.O., Thomas, C.P., 2011. Potential Impacts of Extensive stormwater Infiltration in Philadelphia. Environmental Engineer.

Malaguerra, F., Albrechtsen, H.J., Thorling, L., Binning, P.J., 2012. Pesticides in water supply wells in Zealand, Denmark: a statistical analysis. Sci Total Environ. 2012;414:433-44.

Manglik, A., Rai, S.N., Singh, V.S., 2004. Modelling of aquifer response to time varying recharge and pumping from multiple basins and wells. J. Hydrol. 292, 23-29.

Mikkelsen, P.S., Weyer, G., Berry, C., Walden, Y., Colandini, V., Poulsen, S., Grotehusmann, D.A., Rohlfing, R., 1994. Pollution from urban stormwater infiltration. Water. Sci. Technol. 29 (1-2), 293-302. 
Peters, C., Keller, S., Sieker, H., Jekel, M., 2007. Potentials of real time control, stormwater infiltration and urine separation to minimize river impacts: dynamic long term simulation of sewer network, pumping stations, pressure pipes and waste water treatment plant. Water Sci. Technol. 56 (10), 1-10.

Petersen, C.O.R., Jacobsen, P., Mikkelsen, P.S., 1994. Design of stormwater infiltration for reduction of combined sewer overflow (CSO). Water Sci. Technol. 30 (1), 53-61.

Petersen, C.R., Jacobsen, P., Mikkelsen, P.S., 1995. Nedsivning af regnvand-dimensionering. (Stormwater infiltration-design methods). Spildevandskomiteen, Skrift, 25.

Rao, N.H., Sarma, P.B.S., 1983. Recharge to finite aquifer from strip basins. J. Hydrol. 66, 245252.

Revitt, M., Ellis, B., Scholes, L., 2003. Report 5.1 Review of the use of stormwater BMPs in Europe. In: Project under EU RTD 5th Framework Programme. WP5/T5.1/D5.1. Middlesex University.

Roldin, M., Fryd, O., Jeppesen, J., Mark, O., Binning, P.J., Mikkelsen, P.S., Jensen, M.B. 2012a. Modelling the impact of soakaway retrofits on combined sewage overflows in a $3 \mathrm{Km}(2)$ urban catchment in Copenhagen, Denmark. Journal of Hydrology 452, 64-75.

Roldin, M., Mark, O., Kuczera, G., Mikkelsen, P.S., Binning, P.J. 2012b. Representing soakaways in a physically distributed urban drainage model - upscaling individual allotments to an aggregated scale. Journal of Hydrology 414-415, 530-538.

Roldin, M., Locatelli, L., Mark, O., Mikkelsen, P.S., Binning, P.J., 2013. A simplified model of soakaway infiltration interaction with a shallow groundwater table. Journal of Hydrology 497(0): 165-175.

Sin G., Gernaey K.V., Neumann, M.B., van Loosdrecht, M.C.M., Gujer, W., 2010. Global sensitivity analysis in wastewater treatment plant model applications: prioritizing sources of uncertainty. Water research, 45,639-651. 
Thompson, A., Nimmer, M., Misra, D., 2010. Effects of variations in hydrogeological parameters on water-table mounding in sandy loam and loamy sand soils beneath stormwater infiltration basins. Hydrogeology Journal 18(2): 501-508.

Van Genuchten, M.T., 1980. A closed-form equation for predicting the hydraulic conductivity of unsaturated soils. Soil Sci. Soc. Am. J. 44, 892-898.

Vrugt, J.A., ter Braak, C.J.F., Diks C.G.H, Higdon, D., Robinson, B.A., Hyman, J.M., 2009. Accelerating Markov chain Monte Carlo simulation by differential evolution with selfadaptive randomized subspace sampling, International Journal of Nonlinear Sciences and Numerical Simulation, 10(3), 273-290.

Warnaars, E., Larsen, A.V., Jacobsen, P., Mikkelsen, P.S., 1999. Hydrologic behaviour of stormwater infiltration trenches in a central urban area during $23 / 4$ years of operation. Water Sci. Technol. 39 (2), 217-224.

Weibull, W., 1939. A statistical theory of strength of materials. Ing. Vetensk. Akad Handl. 151, 145.

Wong, T.H.F., Brown R.R., 2009. The water sensitive city: principles for practice. Water Science and Technology 60(3): 673-682

Xiao, Q., McPherson, E.G., Simpson, J.R., Ustin, S.L., 2007. Hydrologic processes at the urban residential scale. Hydrol. Process. 21, 2174-2188.

Zimmermann, H.-J., 2000. An application oriented view of modeling uncertainty. European Journal of Operational Research, 122:190-198. 


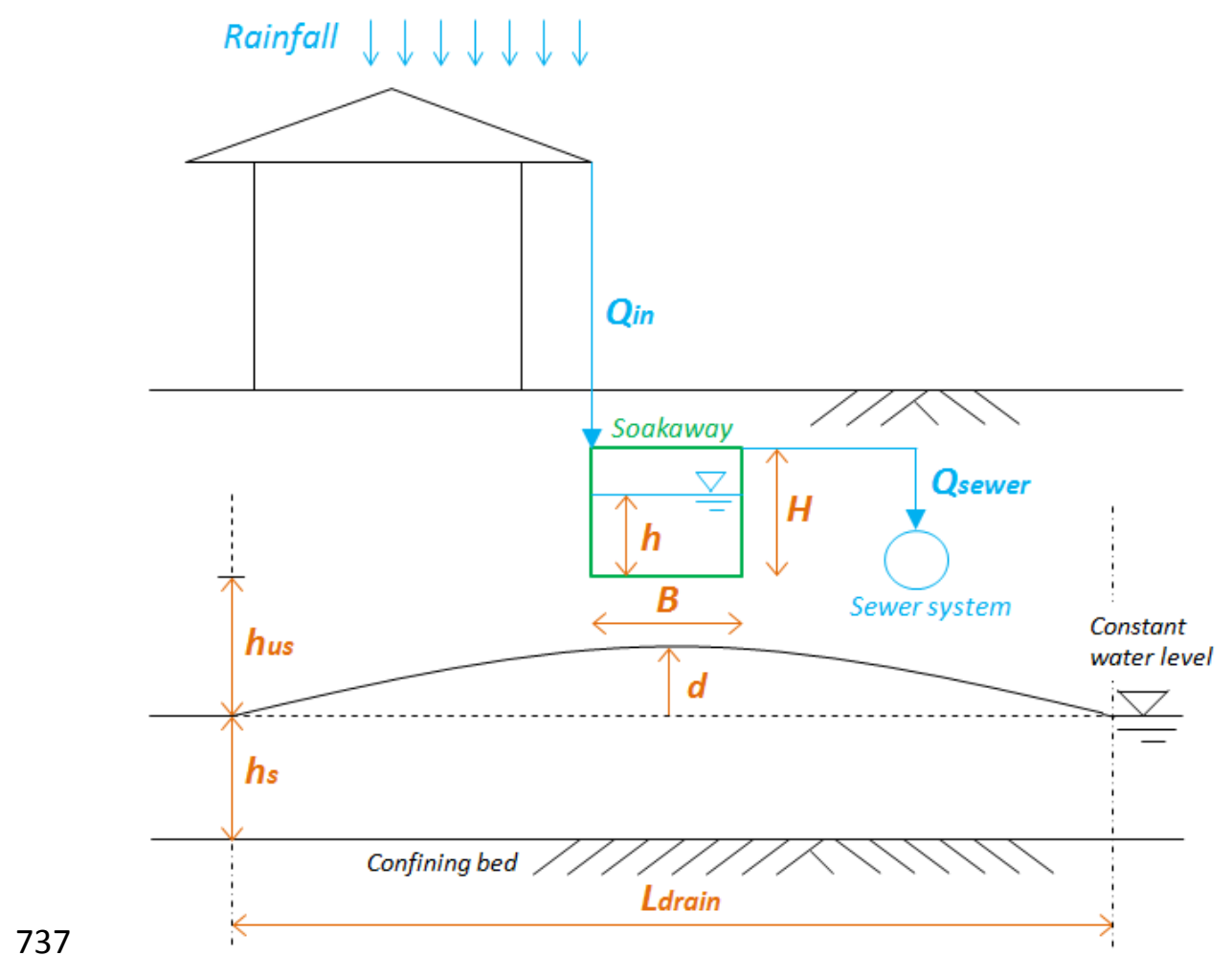

Figure 1. Sketch of the infiltration trench and the groundwater mound system.

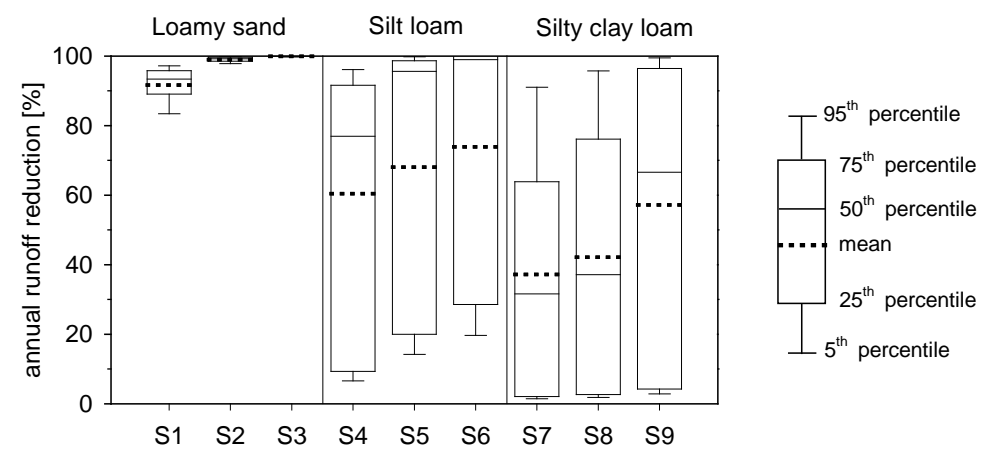

Figure 2. Annual stormwater runoff reduction for the 9 scenarios from the Simple Model 

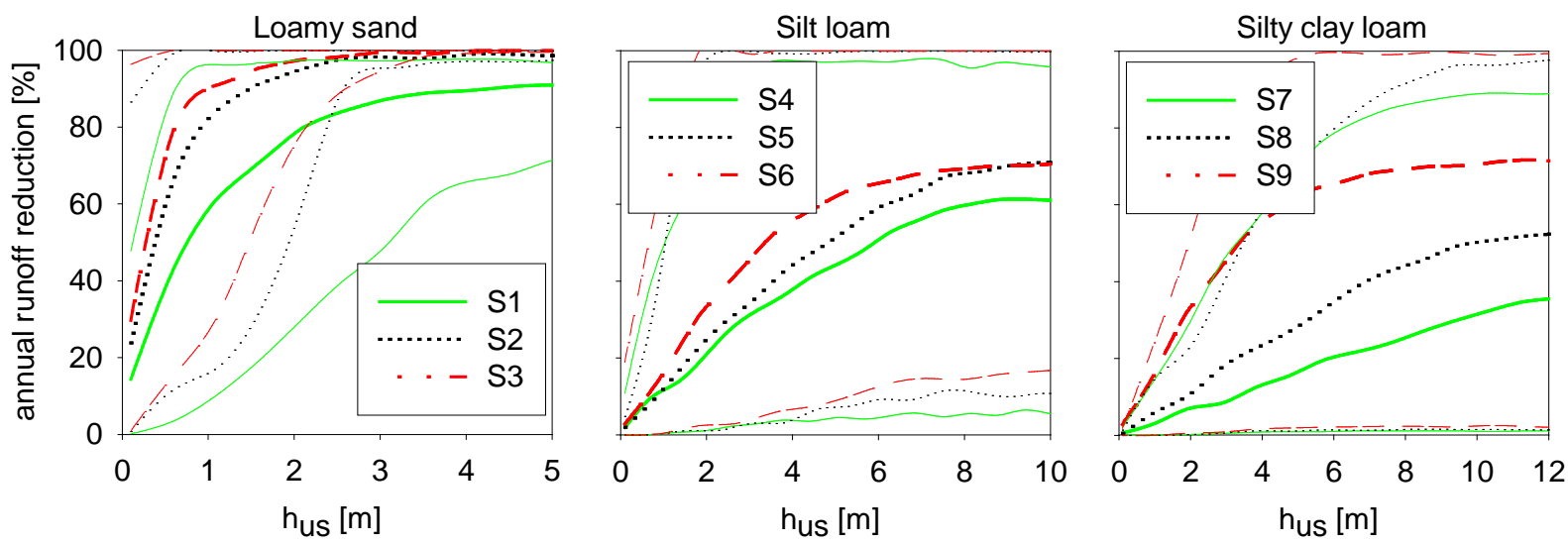

744

Figure 3. Annual stormwater runoff reduction as a function of the unsaturated depth. The

thicker lines represent the mean, whereas the thinner lines show the 5th and 95th percentiles.

The uncertainty bounds of annual runoff reduction include the effect of inter-annual variation and variability of model input parameters, particularly $\mathrm{K}$.
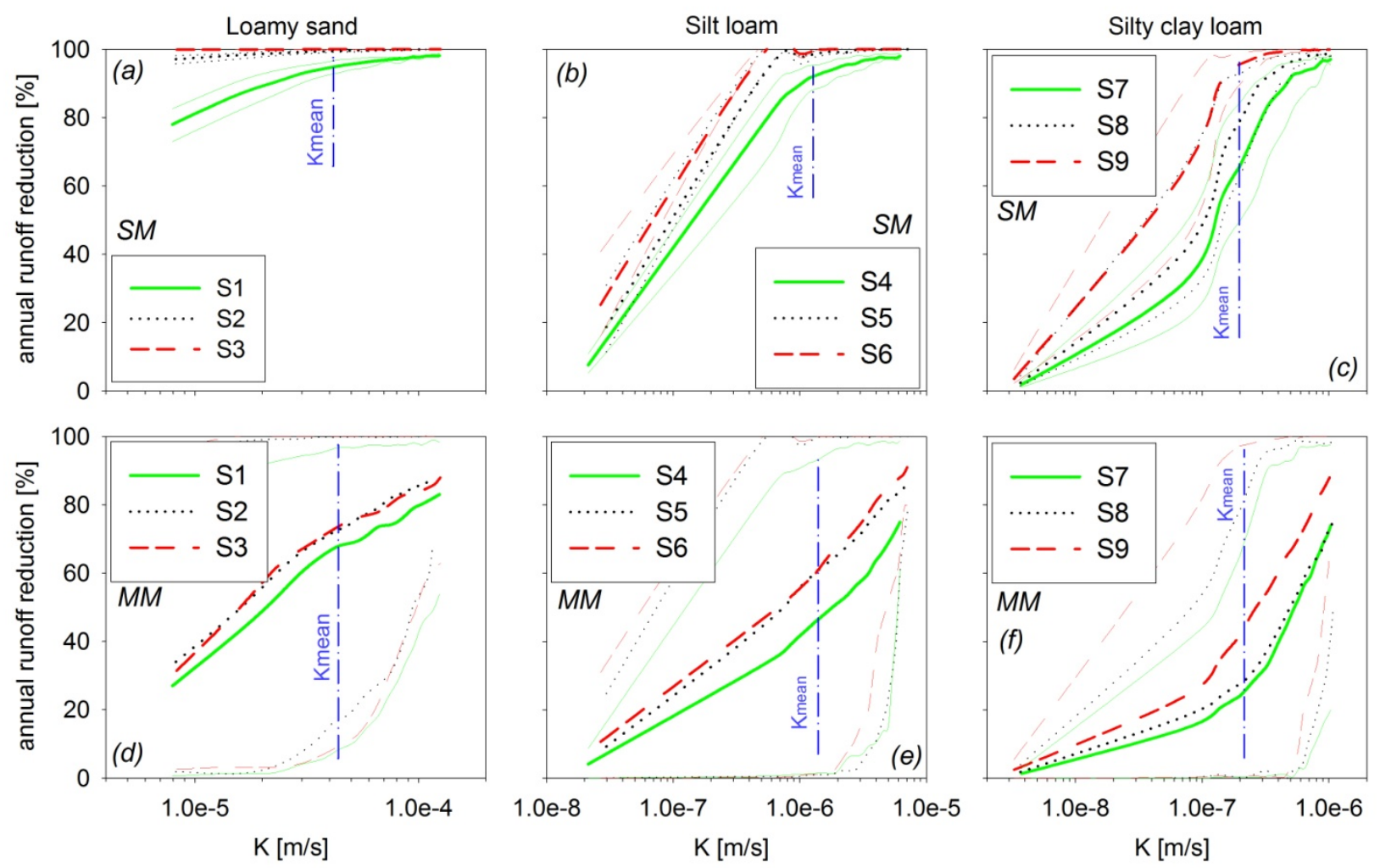

Figure 4. Annual stormwater runoff reduction as a function of the hydraulic conductivity for the

2 models (SM and MM). The thicker lines represent the mean, whereas the thinner lines show 
753 the 5th and 95th percentiles. The uncertainty bounds of annual runoff reduction include the

754 effect of inter-annual variation and variability of model input parameters, particularly $\boldsymbol{h}_{u s}$.

755 

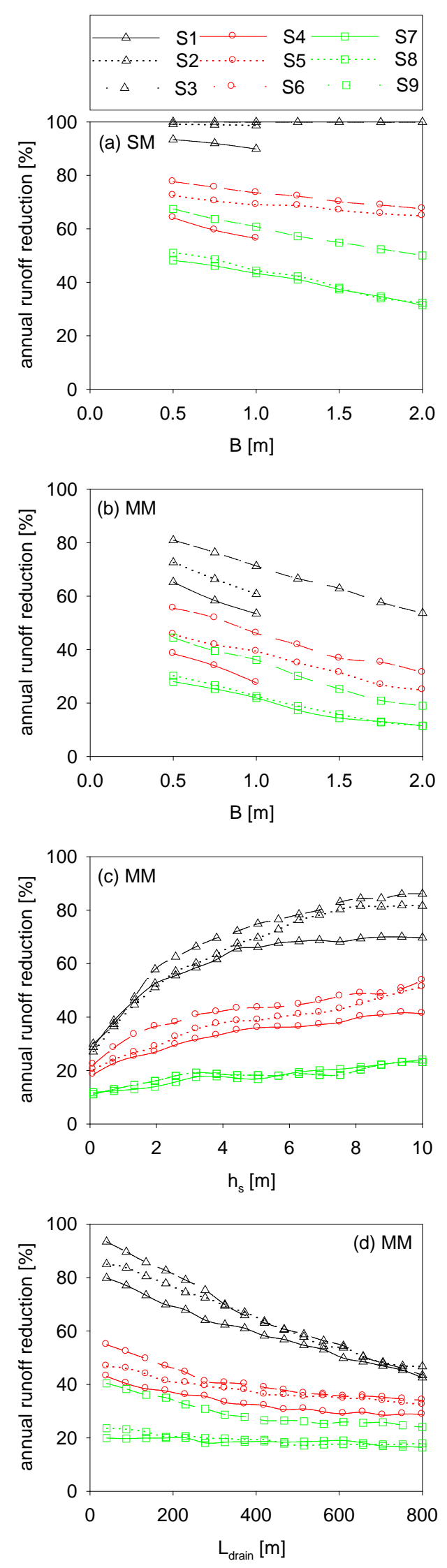

757 Figure 5. Annual stormwater runoff reductions as a function of $B, h_{s}$ and $L_{d r a i n}$. Simple Model 758 (SM) and Model with Mounding (MM). 

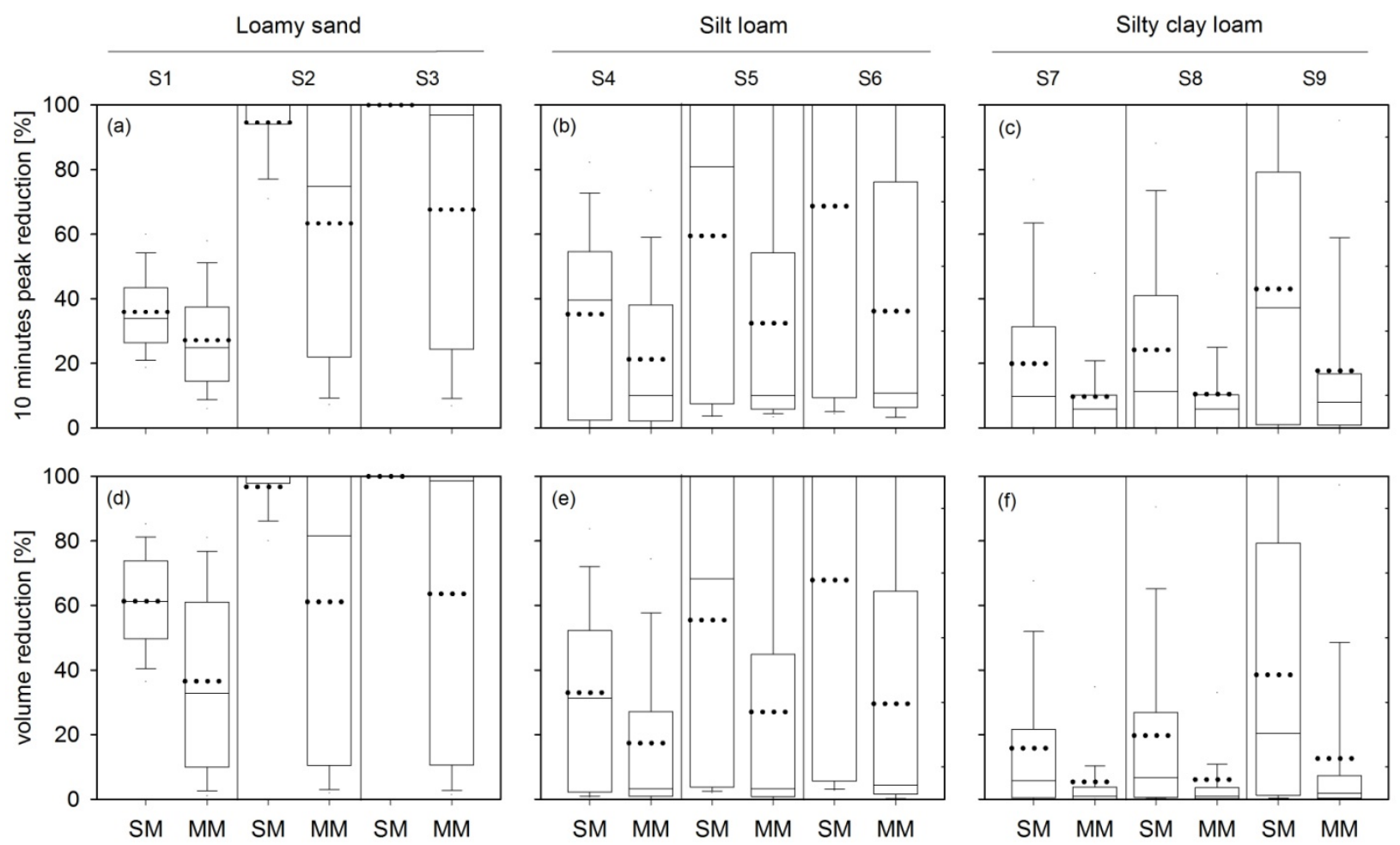

Figure 6. Single event peak and volume runoff reduction for rain events of 0.5-1 year return
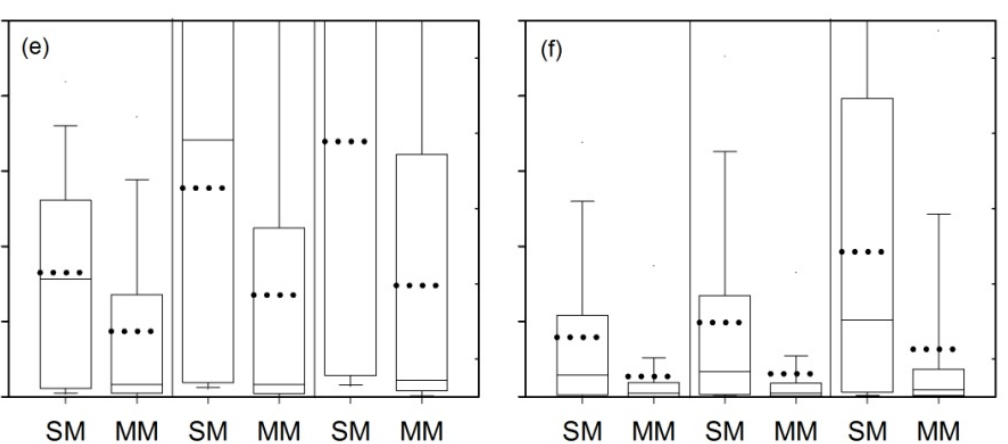

period. Simple Model (SM) and Model with Mounding (MM). The uncertainties in the SM are mostly due to $K$ variability, whereas in the $M M$ they are due to $K$ and $h_{u s}$ variability. 


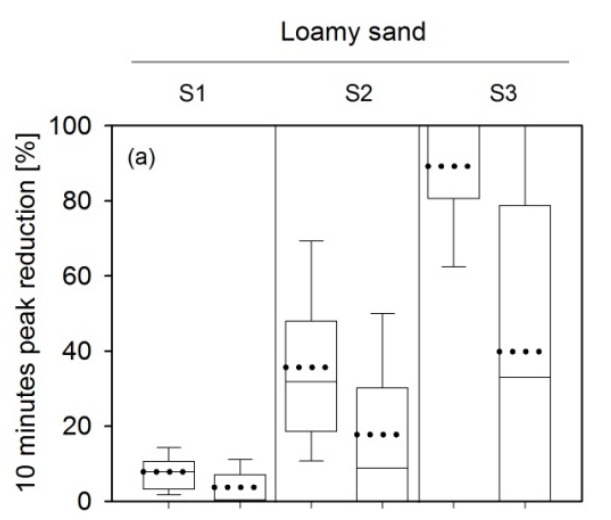

\begin{tabular}{ccc}
\multicolumn{3}{c}{ Silt loam } \\
\hline S4 & S5 & S6
\end{tabular}
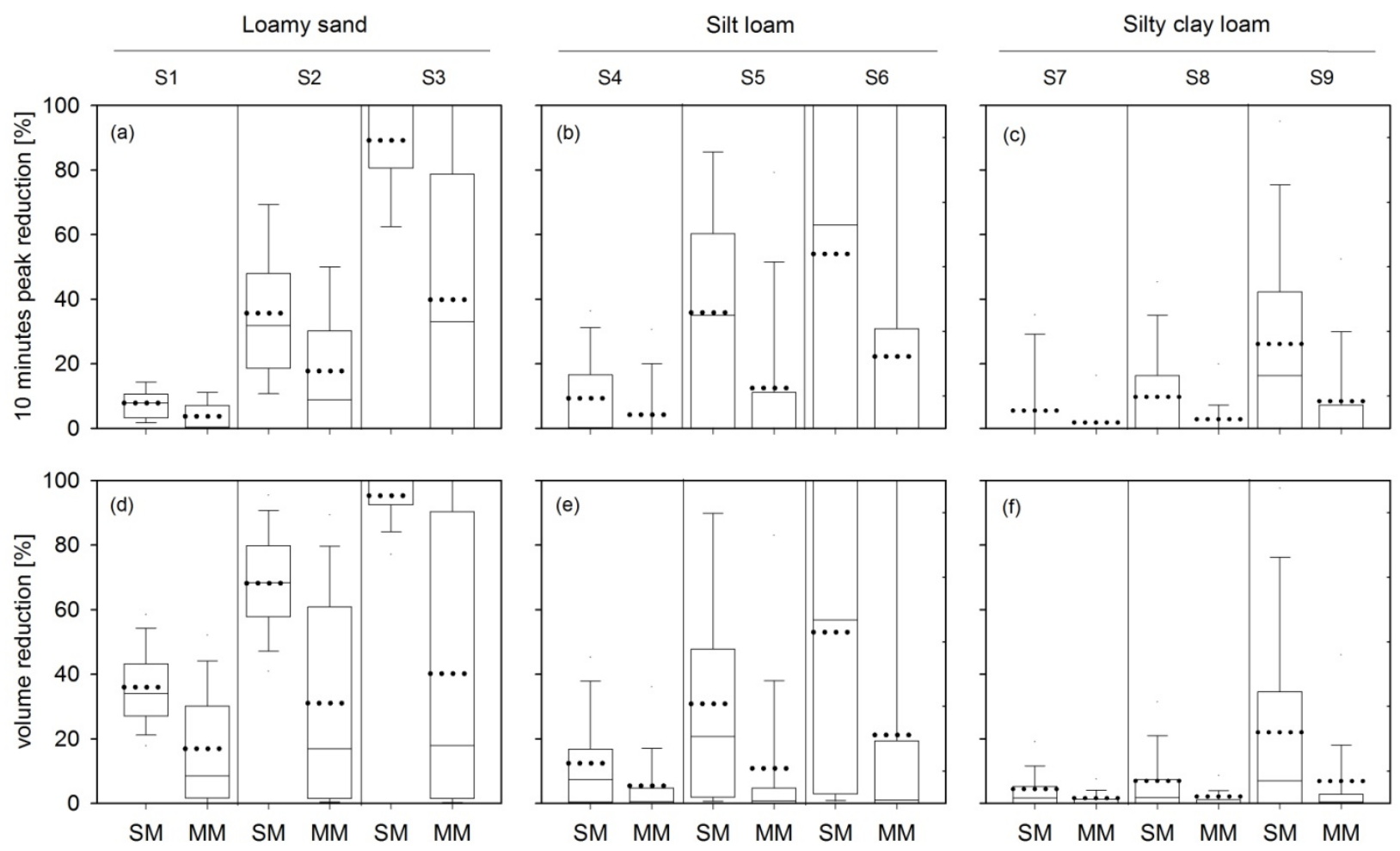

Figure 7. Single event peak and volume runoff reduction for rain events of 5-10 year return period. Simple Model (SM) and Model with Mounding (MM). The uncertainties in the $S M$ are mostly due to $K$ variability, whereas in the $M M$ they are due to $K$ and $h_{u s}$ variability.

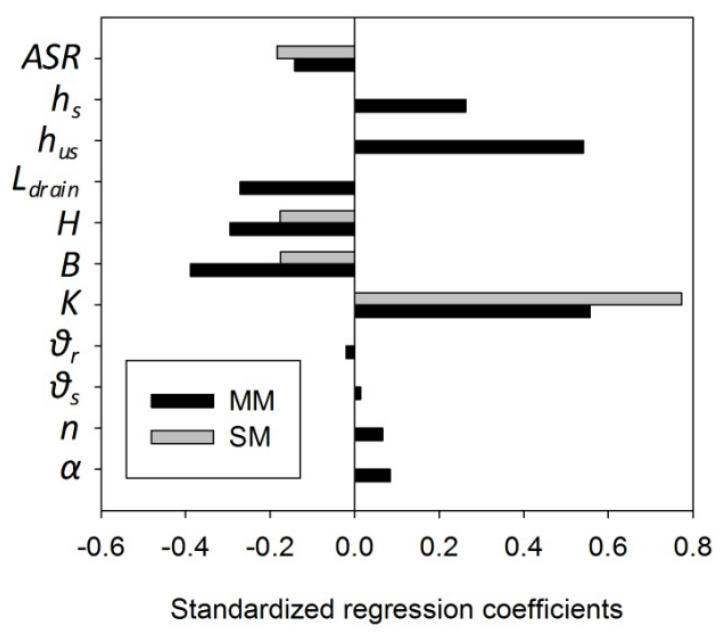

Figure 8. Standardized regression coefficients illustrating the results of the sensitivity analysis for Scenario 5, based on input defined in Table 3. 

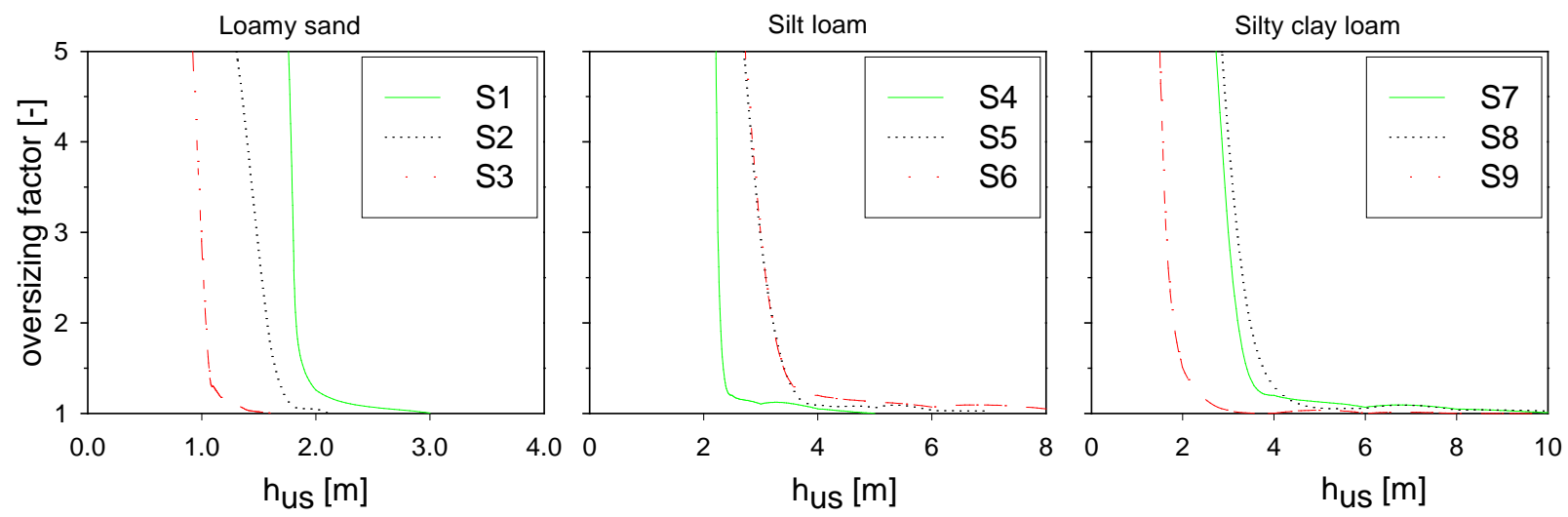

775 Figure 9. Correction factor as a function of the unsaturated depth.

776

777 


\begin{tabular}{|c|c|c|c|c|c|c|}
\hline & Parameter & Description & Value & Unit & $\begin{array}{l}\text { Simple } \\
\text { Model } \\
\text { (SM) }\end{array}$ & $\begin{array}{l}\text { Model with } \\
\text { Mounding } \\
\text { (MM) }\end{array}$ \\
\hline \multirow[t]{6}{*}{ Soil parameters } & $\alpha$ & Van Genuchten parameter & & $\mathrm{m}^{-1}$ & & $\mathrm{X}$ \\
\hline & $n$ & Van Genuchten parameter & & - & & $\mathrm{X}$ \\
\hline & $m$ & Van Genuchten parameter & $1-1 / \mathrm{n}$ & - & & \\
\hline & $\theta_{s}$ & Saturated moisture content & & - & & $\mathrm{X}$ \\
\hline & $\theta_{r}$ & Residual moisture content & & - & & $\mathrm{X}$ \\
\hline & K & Saturated hydraulic conductivity & & $\mathrm{m} / \mathrm{s}$ & $\mathrm{X}$ & $\mathrm{X}$ \\
\hline \multirow{6}{*}{$\begin{array}{l}\text { Infiltration } \\
\text { trenche } \\
\text { parameters }\end{array}$} & $L$ & Length of the infiltration trench & & $\mathrm{m}$ & & \\
\hline & $B$ & Width of the infiltration trench & & $\mathrm{m}$ & $\mathrm{X}$ & $\mathrm{X}$ \\
\hline & $H$ & Height of the infiltration trench & & $\mathrm{m}$ & $\mathrm{X}$ & $\mathrm{X}$ \\
\hline & $\varphi$ & Porosity of the filling material & & - & & \\
\hline & ASR (Area/ & 'Connected impervious area’ / & & $\mathrm{m}^{2} / \mathrm{m}^{3}$ & $\mathrm{X}$ & $\mathrm{X}$ \\
\hline & Storage Ratio) & 'Infiltration trench volume' & & & & \\
\hline \multirow{2}{*}{$\begin{array}{l}\text { Unsaturated and } \\
\text { saturated zone }\end{array}$} & $h_{u s}$ & Thickness of the unsaturated zone & & $\mathrm{m}$ & & $\mathrm{X}$ \\
\hline & $h_{s}$ & Thickness of the saturated zone & & $\mathrm{m}$ & & $\mathrm{X}$ \\
\hline Draining distance & $L_{\text {drain }}$ & Length of the model domain & & $\mathrm{m}$ & & $\mathrm{X}$ \\
\hline
\end{tabular}

\begin{tabular}{|c|c|c|c|c|c|c|c|c|c|}
\hline \multirow[b]{2}{*}{ 赵 } & \multirow[b]{2}{*}{ Description } & \multicolumn{3}{|c|}{ Infiltration trench design } & \multirow[b]{2}{*}{$\begin{array}{l}\text { B ** } \\
{[\mathrm{m}]}\end{array}$} & \multirow[b]{2}{*}{$\begin{array}{l}\mathbf{H} * * \\
{[\mathbf{m}]}\end{array}$} & \multirow[b]{2}{*}{$\begin{array}{l}\mathbf{h}_{\mathrm{us}} * * \\
{[\mathbf{m}]}\end{array}$} & \multirow[b]{2}{*}{$\begin{array}{l}\mathbf{h}_{\mathrm{s}} * * \\
{[\mathrm{~m}]}\end{array}$} & \multirow[b]{2}{*}{$\begin{array}{l}\mathbf{L}_{\mathrm{drain}} * * \\
{[\mathbf{m}]}\end{array}$} \\
\hline & & $\begin{array}{l}\text { Design } \\
\text { return } \\
\text { period } \\
\text { [years]* }\end{array}$ & $\begin{array}{l}\text { Area/Storage } \\
\text { Ratio } \\
{\left[\mathrm{m}^{2} / \mathbf{m}^{3}\right]}\end{array}$ & $\begin{array}{l}\text { Storage depth } \\
\text { [mm] }\end{array}$ & & & & & \\
\hline S1 & $\begin{array}{l}\text { Small infiltration } \\
\text { trench in loamy } \\
\text { sand }\end{array}$ & 0.1 & $200-230$ & $4-5$ & $0.5-1$ & $0.5-1$ & $0-5$ & $1-10$ & $40-800$ \\
\hline S2 & $\begin{array}{l}\text { Medium } \\
\text { infiltration } \\
\text { trench in loamy } \\
\text { sand }\end{array}$ & 1 & $75-90$ & $11-13$ & $0.5-1$ & $0.5-1$ & $0-5$ & $1-10$ & $40-800$ \\
\hline S3 & $\begin{array}{l}\text { Large infiltration } \\
\text { trench in loamy } \\
\text { sand }\end{array}$ & 10 & $35-45$ & $22-29$ & $0.5-2$ & $0.5-1$ & $0-5$ & $1-10$ & $40-800$ \\
\hline S4 & $\begin{array}{l}\text { Small infiltration } \\
\text { trench in silt } \\
\text { loam }\end{array}$ & 0.1 & $55-70$ & $14-18$ & $0.5-1$ & $0.5-1$ & $0-10$ & $1-10$ & $40-800$ \\
\hline S5 & $\begin{array}{l}\text { Medium } \\
\text { infiltration } \\
\text { trench in silt } \\
\text { loam }\end{array}$ & 1 & $20-28$ & $36-50$ & $0.5-2$ & 1 & $0-10$ & $1-10$ & $40-800$ \\
\hline S6 & $\begin{array}{l}\text { Large infiltration } \\
\text { trench in silt } \\
\text { loam }\end{array}$ & 5 & $14-18$ & $56-71$ & $0.5-2$ & 1 & $0-10$ & $1-10$ & $40-800$ \\
\hline S7 & $\begin{array}{l}\text { Small infiltration } \\
\text { trench in silty } \\
\text { clay loam }\end{array}$ & 0.1 & $30-40$ & $25-33$ & $0.5-2$ & $0.5-1$ & $0-15$ & $1-10$ & $40-800$ \\
\hline S8 & $\begin{array}{l}\text { Medium } \\
\text { infiltration } \\
\text { trench in silty } \\
\text { clay loam }\end{array}$ & 0.2 & $20-28$ & $36-50$ & $0.5-2$ & 1 & $0-15$ & $1-10$ & $40-800$ \\
\hline
\end{tabular}




\begin{tabular}{|c|c|c|c|c|c|c|c|c|c|}
\hline S9 & $\begin{array}{l}\text { Large infiltration } \\
\text { trench in silty } \\
\text { clay loam }\end{array}$ & 1 & $12-15$ & $67-83$ & $0.5-2$ & 1 & $0-15$ & $1-10$ & $40-800$ \\
\hline
\end{tabular}

781

782

Table 3. Soil input parameters

\begin{tabular}{lllllll}
\hline & \multicolumn{2}{l}{ Loamy sand } & \multicolumn{2}{c}{ Silt loam } & \multicolumn{2}{l}{ Silty clay loam } \\
& Mean & STD & Mean & STD & Mean & STD \\
\hline$\alpha\left[m^{-1}\right]^{*}$ & 12.4 & 4.3 & 2.0 & 1.2 & 1.0 & 0.6 \\
$n^{*}$ & 2.28 & 0.27 & 1.41 & 0.12 & 1.23 & 0.06 \\
$\theta_{s} *$ & 0.41 & 0.09 & 0.45 & 0.08 & 0.43 & 0.07 \\
$\theta_{r} *$ & 0.057 & 0.015 & 0.067 & 0.015 & 0.089 & 0.009 \\
$K[\mathrm{~m} / \mathrm{s}] * *$ & $4.05 \cdot 10^{-5}$ & $3.16 \cdot 10^{-5}$ & $1.25 \cdot 10^{-6}$ & $3.42 \cdot 10^{-6}$ & $1.94 \cdot 10^{-7}$ & $5.3 \cdot 10^{-7}$ \\
\hline$*$ Normal distribution & \multicolumn{4}{l}{} \\
$* *$ Log-Normal distribution (non-transformed Mean and STD) & & \\
\hline
\end{tabular}

783

784 Tabel 3. Threshold value of unsaturated depth for the model scenarios.

\begin{tabular}{llll}
\hline Soil type & Scenario & $\begin{array}{l}\text { Infiltration trench } \\
\text { design return } \\
\text { period }[\mathrm{y}]\end{array}$ & $\begin{array}{l}\text { Threshold unsaturated } \\
\text { depth } h_{\text {us }}[\mathrm{m}]\end{array}$ \\
\hline \multirow{2}{*}{ Loamy sand } & S1 & 0.1 & 3 \\
& $\mathrm{~S} 2$ & 1 & 2 \\
Silt loam & S & 10 & 1.5 \\
& S4 & 0.1 & 8 \\
Silty clay & S6 & 1 & 8 \\
loam & S7 & 5 & 6.5 \\
& S8 & 0.1 & 12 \\
& S9 & 0.2 & 12 \\
\hline
\end{tabular}

785 